\title{
Małgorzata Karwatowska Uczeń $w$ świecie wartości Wydawnictwo UMCS, Lublin 2010, ss. 182
}

Wartość to $\mathrm{w}$ potocznym rozumieniu wszystko co cenne, pożądane, co stanowi przedmiot obowiązków, zmysłu moralnego, powinności, jest kryterium zachowań, treścią kanonów piękna, itp. ${ }^{1}$ We współczesnym świecie, pełnym sprzeczności, odmiennych światopoglądów i rozmaitych idei, wartości i ich hierarchia ciągle ulegają zmianom, a niekiedy kompletnemu pomieszaniu $\mathrm{z}$ antywartościami. Na straży wartości od wieków stoi tradycja i rodzina, w której człowiek winien być wychowywany ku wartościom. W znaczącej mierze powinna je wspierać szkoła. Programy wychowawcze i zorientowanie procesu dydaktycznego na kształcenie postaw społecznie oczekiwanych są pewną bazą do podjęcia przez nauczycieli, którzy w środowisku szkolnym pełnią również funkcją wychowawców, właściwych działań na rzecz podnoszenia jakości życia indywidualnego i społecznego, co warunkuje realizacja określonego systemu wartości ${ }^{2}$. Kształcenie tego systemu ma charakter procesualny, odbywa się stopniowo, w miarę rozwoju człowieka i jego dorastania. Szkoła może nadawać temu procesowi właściwy i skuteczny bieg.

Szczególne zadania ciążą tu na poloniście jako nauczycielu od wartości ${ }^{3}$. Wiadomo, że odwołuje się on przede wszystkim do powszechnie akceptowanych wzorców utrwalonych w kulturze i literaturze, dokonuje

\footnotetext{
1 Por. Wartość, [w:] G. Vesey i P. Foulkes, Słownik encyklopedyczny. Filozofia, Warszawa 1997, s. 343.

2 Zob. J. Gajda, Wartości w życiu człowieka, Lublin 1997, s. 254.

3 Por. E. Nowel, Aksjologia - summum bonum edukacji polonistycznej, ,Język Polski w Gimnazjum", nr 3, 2008/2009, s. 5.
} 
analizy wartości w określonych kontekstach, przybliża ich naturę, skłania do refleksji nad nimi, inspiruje uczniów do własnych wyborów i ustanawiania hierarchii wartości, zatem jego zadanie nie jest łatwe, wymaga poczucia odpowiedzialności oraz przygotowania merytorycznego i metodycznego.

Wobec tych wyzwań - stale stojących przed polonistą - książka Małgorzaty Karwatowskiej wydaje się świeżym gruntem, na którym śmiało, w sposób niebanalny można budować bardzo efektowne i efektywne lekcje języka polskiego, a więc opierać codzienną praktykę nauczycielską. Publikacja Uczeń $w$ świecie wartości stanowi jeden z elementów stwarzających warunki do tego, aby nauczyciele mogli uczyć sensu wartości i przygotowywać uczniów do ich dostrzegania i przyswajania, kształcić umiejętność życia wartościami.

We wstępie autorka ukazuje potrzebę omawiania zagadnień, które są związane z uświadamianiem poprzez "zastanawianie się nad istotą i rolą wartości w życiu każdego człowieka". Sama zaś wpisuje się w to działanie, nie tylko podejmując $w$ swojej pracy rozważania teoretyczne o nazwach wartości, ale też przedstawiając na podstawie zgromadzonego materiału językowego, rozumienie wybranych wartości przez młodzież, licealistów, ludzi wchodzących w dorosłe życie, przyszłych, rodzimych inteligentów. Za podstawę autorka przyjmuje językowy wymiar wartości, ponieważ właśnie na tym poziomie poznania wartości ożywają, kiedy człowiek uświadamia sobie treść, znaczenie słów i się do nich odnosi. W ten sposób bezpośrednio odbywa się kształtowanie świadomości aksjologicznej młodych ludzi. To bardzo ważne, bo „od świadomości aksjologicznej i stopnia interioryzacji wartości moralnych i kulturowych zależy nasza przyszłość" - jak stwierdza Bogdan Walczak, recenzent prezentowanej książki. Ponadto M. Karwatowska, co bardzo cenne, podaje liczne, inspirujące propozycje rozwiązań metodycznych, które można wykorzystać na różnych etapach edukacyjnych, aby problematyka aksjologiczna w ciekawy i łatwy sposób, systematycznie i świadomie była podejmowana na lekcjach języka polskiego.

Prezentowany tom tworzą trzy części główne wyodrębnione w sposób naturalny, właściwy dla przedmiotu opracowania (pierwsza część dotyczy wartości pozytywnych, druga negatywnych, a trzecia ambiwalentnych), co odzwierciedla i ujawnia istniejący w świecie „pejzaż aksjologiczny". Otwierają zbiór Refleksje na temat wartości. Autorka zwraca tu uwagę czytelnika na fakt, że „to człowiek stoi w centrum wartości, on 
jest ich nosicielem i to on je realizuje (...), a czasami odrzuca, kwestionuje, podważa ich sens..." (s. 5). Dalej określa istotę, cele, sens, znaczenie wartości z punktu widzenia wybranych przedstawicieli filozofii i etyki, m.in. Romana Ingardena. Szczegółowiej omawia poświęcone wartościom prace językoznawców: Anny Wierzbickiej, Zofii Zaron, Janiny Puzyniny, tworząc tło merytoryczne własnych refleksji, omówień wyników badań i proponowanych rozwiązań metodycznych.

Zamysł kompozycyjny konsekwentnie realizowany w poszczególnych paragrafach książki można prześledzić na podstawie szkicu O sumieniu. Najpierw autorka wprowadza czytelnika w zagadnienie, przywołując definicje i etymologię słowa sumienie. Następnie omawia na przykładach jego łączliwość. Potem przywołuje i analizuje aforyzmy, sentencje i przysłowia poświęcone sumieniu, z których wynika, że jego główne cechy to: uczciwość i niesprzedajność. Kolejny fragment stanowi odwołanie do Sumienia w chrześcijańskiej myśli etycznej, a po nim znajdzie czytelnik Obraz sumienia zawarty $w$ języku licealistów. Współtworzą ów obraz następujące paragrafy: Skojarzenia uczniowskie, Łq̨czliwość słowa sumienie z czasownikami i przymiotnikami w wypowiedziach licealistów, Definicje uczniowskie, Porównania uczniowskie, "Kolory" sumienia, które powstały w oparciu o materiał językowy zebrany na podstawie poleceń wykonywanych przez uczniów. Szkic kończy przejrzyste, zawarte w punktach podsumowanie wynikające $z$ rozważań teoretycznych i analizy materiału językowego. Odrębnym elementem kompozycyjnym, ale dołączonym do każdego szkicu, jest scenariusz zajęć poświęcony danej wartości, która była przedmiotem omówienia. Po szkicu o sumieniu znajdujemy scenariusz lekcji opartej na interpretacji wiersza Wisławy Szymborskiej i aforyzmach Stanisława Jerzego Leca. Ta propozycja metodyczna zakłada aktywizację uczniów, uwzględnia ich indywidualne zdolności i umiejętności, odwołuje się do teorii wielointeligencji.

Kolejne części prezentowanego zbioru komponowane są na podobnej zasadzie: po rozważaniach teoretycznych (z interesującą bibliografią) zamieszczono propozycje opracowania metodycznego, które podpowiadają możliwości tworzenia ćwiczeń językowych wokół konkretnych nazw wartości. Niezwykle cenne wydają się te metodyczne wskazówki. Odsyłają one ucznia do samodzielnych poszukiwań w oparciu o umiejętności z zakresu samokształcenia, pozwalają na ciągłe obcowanie z żywym językiem oraz podejmowanie prób jego badania i analizowania, co pogłębia świadomość językową poprzez praktyczne działanie. W zadaniach 
do tekstu znajduje czytelnik przykłady właściwie skonstruowanych, klarownych pytan (np. s. 49-50, 60-62). W ćwiczeniach z tekstem literackim są propozycje takich zadań dla ucznia, które pozwolą kształcić umiejętność pracy ze słownikiem np. etymologicznym i frazeologicznym, przypomnieć i utrwalić wiedzę z zakresu fleksji i składni, wzbogacą słownik czynny ucznia poprzez ćwiczenia w wyszukiwaniu synonimów, antonimów i wyrazów pokrewnych do takich słów jak np. tolerancja (s. 62).

Wraz z lekturą kolejnych fragmentów i rozdziałów książki odnajduje się w niej interesującą wiedzę merytoryczną i twórcze rozwiązania metodyczne zorganizowane wokół wartości pozytywnych, społecznie pożądanych, jak: szacunek, tolerancja, szczęście, oraz wartości negatywnych reprezentowanych przez kłamstwo, cierpienie i zazdrość. Do nich zostały dołączone wartości ambiwalentne: kariera, wolność i samotność. Zestaw zamieszczonych $\mathrm{w}$ opracowaniu propozycji można dowolnie rozwijać, naśladując twórczo, w zgodzie z sumieniem wychowawcy i ku własnej satysfakcji, pomysły M. Karwatowskiej.

Niewątpliwie wartością pracy jest też bogata bibliografia, która otwiera czytelnika na nowe źródła poznania. Jednak lektura omawianej publikacji budzi też wywiedzioną z praktyki zawodowej smutną refleksję. Otóż tego rodzaju opracowania stosunkowo rzadko trafiają obecnie (z wielu różnych przyczyn) do rąk czytelników, polonistów - nauczycieli wartości jako właściwych, najbardziej uprawnionych adresatów. A szkoda, ponieważ liczne walory książki Małgorzaty Karwatowskiej - merytoryczne i praktyczne - skłaniają do refleksji i mogą być źródłem inspiracji, własnej interpretacji, walki ze szkolną nudą, propozycją otwarcia się na pracę indywidualną, twórczą i ciekawą, satysfakcjonującą nauczyciela i ucznia. Jednak wobec istniejącej rzeczywistości omawiana pozycja raczej stanowi swoisty głos we współcześnie dostrzeganej tendencji do realizacji zmian na płaszczyźnie dyskursu. Tymczasem od dyskursu do działania, tak jak od wartości do postaw daleka droga. Pozostaje nadzieja, że do jakiegoś grona polonistów - poszukiwaczy trafi i przemówi Uczeń $w$ świecie wartości. 